\title{
Investigation of solid energy potential of wood and bark obtained from four clones of a 2-year old goat willow
}

\author{
Sim-Hee Han ${ }^{1}$ and Soo-Jeong Shin ${ }^{2 *}$ \\ Department of Forest Genetic Resources, Korea Forest Research Institute, Suwon, South Korea \\ ${ }^{2}$ Department of Wood and Paper Science, Chungbuk National University, Cheongju, South Korea
}

\section{Edited by:}

Rongxin Su, Tianjin University, China

Reviewed by:

Jaime Puna, Instituto Superior de

Engenharia de Lisboa, Portugal

Luis Serrano, University of the

Basque Country, Spain

${ }^{*}$ Correspondence:

Soo-Jeong Shin, Department of Wood and Paper Science, Laboratory of

Plant Biomass Chemistry, Chungbuk

National University, Cheongju,

Chungbuk 361-763, South Korea

e-mail:soojshin@cbnu.ac.kr
To investigate the solid raw material characteristics of willow (Salix caprea) bark and woody core, this study analyzed overall chemical composition, monosaccharide composition, ash content, and main ash composition of both tree components. Significant differences were observed between the two in terms of chemical composition, carbohydrate composition, ash content, and major inorganics. The ash content in bark was 3.8-4.7\%, compared with $0.6-1.1 \%$ in the woody core. Polysaccharide content in the woody core was $62.8-70.6 \%$ but was as low as $44.1-47.6 \%$ in the bark. The main hemicelluloses consisting of monosaccharides were xylose in the case of the woody core, and xylose, galactose, and arabinose in the case of bark. Woody core biomass of willow provides superior solid fuel raw material, as compared with bark biomass, with higher heating values, less ash content, and less slagging-causing material.

Keywords: Salix caprea, ash, slagging, carbohydrate composition, silica

\section{INTRODUCTION}

Fossil fuels are created through the deep burial of biomass produced through photosynthesis, followed by thermochemical reactions, which eventually produce fuels such as coal, oil, and natural gas (Olabi, 2012). As a result of industrialization, these fossil fuels have been used as raw materials for fuels and chemicals, leading to increased greenhouse gas concentration in the atmosphere. The increase in carbon dioxide emissions has brought climate change to the fore as an urgent concern. A solution to the problem will require a shift from fossil fuels to renewable energy sources. The oil shock of the 1970s highlighted the importance of renewable energy resources and of higher biomass production systems (Klass, 1995).

Lignocellulosic biomass is formed by the reduction of carbon dioxide with sunlight at chlorophyll in plants. Sustainable production of biomass is important if lignocellulosic materials are to be used as renewable energy sources (Han et al., 2013a). Destruction of the Amazon and other tropical rainforests for the utilization of wood, or for the creation of agricultural land, leads to a decrease in photosynthetic ability (Cochrane and Barber, 2008). On the contrary, the cultivation of energy crops with annual plants, perennial grasses, or short-rotation coppice, will not diminish the forestland available for biomass supply (Lewandowski et al., 2000). Annual plants or perennial grasses have a higher biomass production rate than the woody biomass, which requires more labor than a short-rotation coppice system (Fischer et al., 2005). Shortrotation coppice production of willow or poplar can be an option for sustainable biomass production, in order to generate bioenergy in a biorefinery.

The main structural components of lignocellulosic biomass are cellulose, hemicelluloses, and lignin. Small amounts of organics (extractives) and inorganics are also found. Cellulose is a homopolymer of glucose, linked through a beta $1 \rightarrow 4$-glucosidic linkage. The characteristic hydrogen bonding ability of cellulose forms a crystalline and amorphous structure. The complicated structure of cellulose hinders attacks by microorganisms. In hardwood and perennial grasses, xylan is the main hemicellulose component, composed of xylose linked through beta $1 \rightarrow 4$ xylosidic linkages. The main hemicellulose in softwood is glucomannan, a copolymer of glucose and mannose. A phenol polymer (lignin) has a repeating unit of phenylpropanoids, linked by the enzymatic radical coupling of monomeric units. Softwood has coniferyl alcohol as its sole monomer, but hardwood has coniferyl alcohol and sinapyl alcohol as copolymers.

Cellulose and hemicelluloses can be hydrolyzed to monomeric saccharides, which can be fermented to alcohol or to organic acids, which have the potential to replace petroleum-based chemical intermediates (Cho et al., 2012). An acid or enzymatic hydrolysis process can be applied for monosaccharide production. Polysaccharide composition in lignocellulosic biomass is important for a fermentation-based liquid fuel processing process. Glucose, mannose, and galactose are easily fermented by microorganisms, but xylose and arabinose are not fully used by major fermenting microorganisms.

Lignocellulosic biomass can be used for solid fuel production, such as in wood pellets. Content and composition of minerals are important considerations, as are heat values. In addition, the chemical composition of main components also affects the energy content of biomass. Lignin $(25.1 \mathrm{MJ} / \mathrm{kg})$ has higher energy content than polysaccharides $(17.5 \mathrm{MJ} / \mathrm{kg}$ ) (Klass, 1998). Higher heating values have been demonstrated for short-rotation cultivation biomass of eucalyptus, alder, and radiate pine, with energy contents of $19.6-20.5 \mathrm{MJ} / \mathrm{kg}$ for woody biomass, $17.4-20.6 \mathrm{MJ} / \mathrm{kg}$ for bark, and $19.5-24.1 \mathrm{MJ} / \mathrm{kg}$ for leaves, respectively (Senelwa and Sims, 1999).

Ashes remain after burning as solid waste, and silicates in minerals form solid residues in the fuel burning system. Ash content 
and composition affect solid fuel quality, through factors such as energy content and operating problems. Higher ash-containing biomass has lower heating values and leads to more dust emission and sintering of equipment (Zamorano et al., 2011), while silica contained in solid fuels leads to sintering tendencies in fuel burners (Ohman et al., 2004).

Bark-containing pellets were found to have a positive effect in terms of lower steam requirements during pellet making, and in terms of higher bulk densities; however, the increase in ash content and sintering were the main disadvantages of higher bark-containing pellet identified (Filbakk et al., 2011).

Short-rotation cultivation for biomass production was introduced for generating a sustainable wood supply (Mirck et al., 2005). Continuous research in this area with willow led to the generation of 10-12 dry tons of biomass per hectare annually (Host et al., 1996). Nutrition in the soil also affects the growth of the plant. In the case of short-rotation coppice production, soil nutrition influenced biomass productivity. Nitrogen, phosphate, potassium, magnesium, and calcium affect the growth of biomass; the optimum content of each nutritional component is important for biomass production (Jug et al., 1999).

Salix belongs to the family Salicaceae, and represents a genus with a broad spectrum of tree and shrub species, mainly distributed over the northern continents. Salix caprea (Goat Willow) is a common species of willow native to Europe, western, and central Asia (Meikle, 1984). It is a deciduous shrub or small tree, reaching a height of 8-10 m rapidly, and more rarely to $13 \mathrm{~m}$. In Korea, willows are considered to be potent plant material for phytoremediation applications, and are also considered to be potential materials for energy production from biomass, due to their being prolific and due to their high growth rates (Vervaeke et al., 2006; Meers et al., 2007). S. caprea planted in most areas in Korea showed a fast growth pattern, particularly during early stages. $S$. caprea occurs both in wet environments (such as riverbanks and lakeshores) and on drier sites, wherever bare soil becomes available due to ground disturbance (Meikle, 1984). In addition, S. caprea shows a high adaptability to different habitat conditions (Dušek and Kvet, 2006).

In this study, we investigated chemical composition and carbohydrate composition of four clones of willow, with respect to their potential as raw materials. Elementary composition, ash content, and main ash components were also investigated as parameters for solid fuel resources. The willow clones exhibited a rapid growth pattern during early stages, and thus, they were grown in most areas of Korea.

\section{MATERIALS AND METHODS MATERIALS}

Willow biomass (S. caprea) was cultivated by the Korea Forest Research Institute, Department of Forest Genetic Resources, Suwon, South Korea. Cuttings of willow twigs (approximately of $10 \mathrm{~cm}$ length and $1 \mathrm{~cm}$ diameter, with three nodes) were propagated in containers with vermiculite in early April 2009. After 7 weeks of propagation, the willow twigs, 40 cuttings (with similar height and basal diameter of sprouts) of each clone were transplanted into the field. The first harvest of 1-year-old cuttings of the seven willow clones was conducted in early March 2010 (Han et al., 2013b). Two-year-old biomass of four willow clones that had shown normal growth performance in the field was harvested in early March 2011. Harvested biomass was separated into stem and bark by hand. Separated stem and bark biomass were air-dried at room temperature for 2 weeks. Dried biomass was cut and milled to $<20$-mesh, using a Willy mill.

\section{METHODS}

\section{Overall chemical composition analysis}

As a consecutive process, acetone-soluble and hot-water soluble extractive contents were measured as per Tappi Standard T204cm97 and T207cm-99 with air-dried bark and stem meal. Extractivesfree samples (200-250 mg, oven-dried) were hydrolyzed using $72 \%$ sulfuric acid $(4.5 \mathrm{~mL})$ for $1 \mathrm{~h}$ at $30^{\circ} \mathrm{C}$ for first hydrolysis, and the hydrolyzed samples were diluted to $4 \%$ sulfuric acid with deionized water. This was followed by another hydrolysis process for $1 \mathrm{~h}$ in an autoclave at $120^{\circ} \mathrm{C}$. The hydrolysis solution was cooled overnight and filtered through a glass filter (1G4), and residues on the glass filter were used to determine Klason lignin content, which was oven-dried at $100^{\circ} \mathrm{C}$ to constant weight.

\section{Carbohydrate compositional analysis of willow biomass}

Extractives-free samples $(70 \mathrm{mg})$ were hydrolyzed with $0.8 \mathrm{~mL}$ of $72 \%$ deuterium sulfuric acid $\left(\mathrm{D}_{2} \mathrm{SO}_{4}\right)$ in deuterium oxide $\left(\mathrm{D}_{2} \mathrm{O}\right)$ at $30^{\circ} \mathrm{C}$ for $1 \mathrm{~h}$. Those samples were diluted with $3.2 \mathrm{~mL}$ of deuterium oxide and autoclaved at $120^{\circ} \mathrm{C}$ for $1 \mathrm{~h}$; hydrolyzates were filtered into a nuclear magnetic resonance (NMR) tube without any neutralization or derivatization.

Acidic filtrates were analyzed by Bruker AVANCE NMR Spectrometer (500 MHz for proton). NMR data were processed using Topspin software, to resolve and integrate the NMR peaks. Anomeric hydrogen peak regions (4.4-5.4 ppm) in NMR spectra were integrated for carbohydrate compositional analysis. NMR operational conditions, as described in the literature (Shin and Cho, 2008), were followed. Due to hydrogen exchange with hydroxyl groups in monosaccharides, HDO (water with replaced a hydrogen by deuterium) was formed from deuterium oxide, and could interfere with anomeric hydrogen peak assignment. This was solved by adjusting the acidity of the analysis solution through the addition of sulfuric acid.

\section{Elementary compositional analysis}

The elementary analysis of $\mathrm{C}, \mathrm{H}, \mathrm{O}$, and $\mathrm{N}$ was conducted using an Elementary Analyzer (EA 1110, CE Instrument, England). Woody core and bark particles smaller than 40 mesh were burned at $1800^{\circ} \mathrm{C}$ and produced nitrogen oxides, $\mathrm{CO}_{2}$, and $\mathrm{H}_{2} \mathrm{O}$, which were analyzed for nitrogen, carbon, and hydrogen content. For analysis of oxygen content, biomass particles ( $<40$ mesh) were pyrolyzed under nitrogen.

As per ISO 1171-1981, inorganics in the woody core and the bark of willow biomass were determined for $2.0 \mathrm{~g}$ of sample using a muffle furnace at $550^{\circ} \mathrm{C}$. Slagging components amongst ashes were determined through inductively coupled plasma atomic emission-spectrometry, for quantification of $\mathrm{Mg}, \mathrm{Ca}, \mathrm{Si}, \mathrm{P}$, and $\mathrm{K}$.

\section{Energy content}

Energy content of biomass was estimated based on chemical composition using the Dulong (Sivapalan et al., 2003) and Ruyter 
(Ruyter, 1982) models. The formulas used in the two models are given below:

1) Dulong model; $\mathrm{CV}$ (Calorimetric value $)=80.80 \% \mathrm{C}+344.60$ $(\% \mathrm{H}-\% \mathrm{O} / 8)+22.50 \% \mathrm{~S}\left(\mathrm{kcal} \mathrm{kg}^{-1}\right)$.

2) Ruyter model; $\mathrm{CV}=0.34 \% \mathrm{C}+1.40 \% \mathrm{H}-0.16 \% \mathrm{O}(\mathrm{MJ}$ $\left.\mathrm{kg}^{-1}\right)$.

Table 1 | Overall chemical composition of different willow cultivar on wood and bark [unit: \% (wt/wt)].

\begin{tabular}{llccccc}
\hline Clones & Ash & $\begin{array}{c}\text { Acetone- } \\
\text { solubles }\end{array}$ & $\begin{array}{l}\text { Hot-water } \\
\text { solubles }\end{array}$ & Lignin & $\begin{array}{c}\text { Polysac- } \\
\text { charides }\end{array}$ \\
\hline Woody & BH-4 & 1.1 & 1.0 & 14.6 & 16.7 & 66.6 \\
core & BH-8 & 1.1 & 0.7 & 18.2 & 17.2 & 62.8 \\
& BH-10 & 0.8 & 0.8 & 11.4 & 18.1 & 68.9 \\
& BH-11 & 0.6 & 0.7 & 10.7 & 17.4 & 70.6 \\
Bark & BH-4 & 3.8 & 4.1 & 25.2 & 22.5 & 44.3 \\
& BH-8 & 4.6 & 3.3 & 20.3 & 24.1 & 47.6 \\
& BH-10 & 4.1 & 5.0 & 23.7 & 23.1 & 44.1 \\
& BH-11 & 4.7 & 1.8 & 19.6 & 29.4 & 44.4
\end{tabular}

\section{RESULTS}

\section{OVERALL CHEMICAL COMPOSITION}

Lignocellulosic biomass consists of cellulose, hemicelluloses, and lignin as main components. Small amounts of extractives and inorganics are also present. In the case of all clones, bark biomass had higher content of ashes, acetone-solubles, hot-water solubles, and lignin, than woody core biomass (Table 1). Bark has more extractives than the woody core, with respect to both acetone-solubles and hot-water solubles (Table 1).

\section{CARBOHYDRATE COMPOSITION}

The ${ }^{1} \mathrm{H}-\mathrm{NMR}$ spectroscopic method was used to investigate the carbohydrate composition in bark and woody core of four clones of goat willow. Peak intensity of anomeric hydrogen was integrated to quantitative analysis as shown in Figure 1.

Due to the presence of fewer polysaccharides in bark than in woody core, bark can produce less liquid fuels in a process based on hydrolysis and fermentation of polysaccharides. As shown in Table 2, polysaccharide content in the woody core was $62.8-70.6 \%$, quite significantly higher than in bark (44.1-47.6\%).

Galactan and arabinan contents were $<1.0 \%$ in woody core biomass, but more than $2.4 \%$ galactan and $4.6 \%$ arabinan

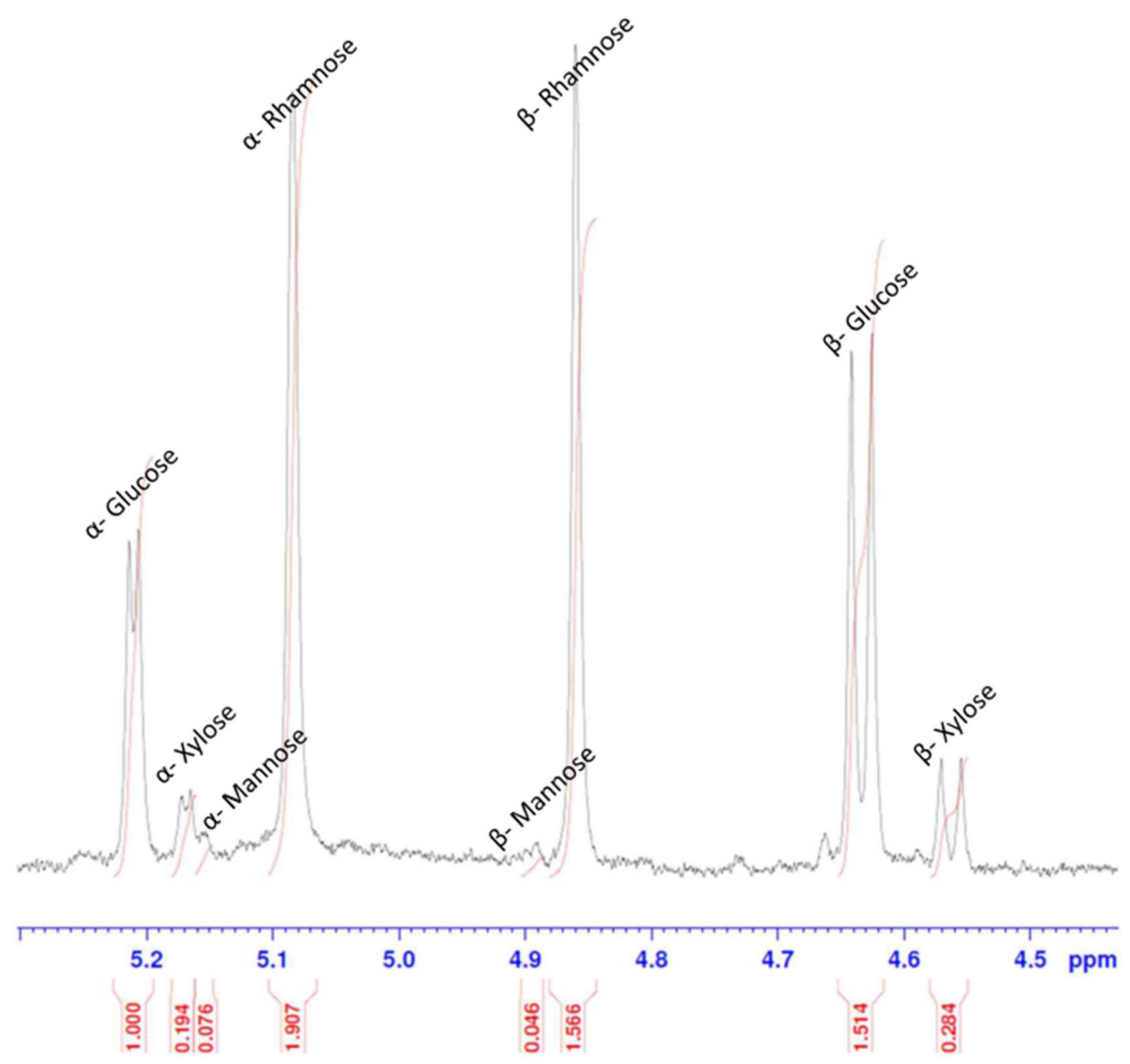

FIGURE 1 | 1H-NMR spectra of anomeric hydrogen peaks from monosaccharides in goat willow. 
Table 2 | Carbohydrate composition of different willow cultivar on wood and bark [unit: \% (wt/wt)].

\begin{tabular}{|c|c|c|c|c|c|c|c|}
\hline & Clones & Polysaccharides & Glucan & Xylan & Mannan & Galactan & Arabinan \\
\hline \multirow[t]{4}{*}{ Woody core } & $\mathrm{BH}-4$ & 66.6 & 45.8 & 19.0 & 1.0 & 0.8 & - \\
\hline & $\mathrm{BH}-8$ & 62.8 & 43.9 & 18.0 & 0.5 & 0.4 & - \\
\hline & $\mathrm{BH}-10$ & 68.9 & 49.2 & 18.5 & 1.0 & 0.3 & - \\
\hline & $\mathrm{BH}-11$ & 70.6 & 50.9 & 19.0 & 0.5 & 0.2 & - \\
\hline \multirow[t]{4}{*}{ Bark } & $\mathrm{BH}-4$ & 44.3 & 27.5 & 7.5 & 0.6 & 3.5 & 5.2 \\
\hline & $\mathrm{BH}-8$ & 47.6 & 31.3 & 8.4 & 0.7 & 2.5 & 4.6 \\
\hline & $\mathrm{BH}-10$ & 44.1 & 28.5 & 6.2 & 0.7 & 2.5 & 6.3 \\
\hline & $\mathrm{BH}-11$ & 44.4 & 27.8 & 8.7 & 0.8 & 2.4 & 4.7 \\
\hline
\end{tabular}

were detected in bark. This might be a result of differences in hemicellulose composition between woody and bark biomass.

\section{ELEMENTARY COMPOSITION}

In elementary analysis of carbon, hydrogen, nitrogen, and oxygen, carbon content was higher in woody core than in bark. The range of carbon content of the four willow clones was from $45.65 \%$ (clone $\mathrm{BH}-11$ ) to $46.87 \%$ (clone $\mathrm{BH}-4$ ) for woody core, and from $44.89 \%$ (clone $\mathrm{BH}-11$ ) to $45.66 \%$ (clone $\mathrm{BH}-4$ ) in bark (in Table 3). In contrast to carbon, hydrogen was greater in the bark than in the woody core. The hydrogen content of the bark was highest in clone BH-11 (6.60\%) and lowest in clones BH-4 and $\mathrm{BH}-8(6.27 \%)$. In the case of woody core, $\mathrm{BH}-11$ had less hydrogen $(6.03 \%)$ than the other three clones (6.19-6.21\%). The highest nitrogen content in bark was recorded for clone BH-11 (2.44\%), with the lowest being in clone BH-4. Nitrogen content in woody core was similar across clones, but differed from values obtained for bark (which ranged from 0.79 to $2.44 \%$ ).

\section{ENERGY CONTENT}

Energy content, as estimated from the Dulong and Ruyter models, was significantly different between the four clones. Based on the energy content estimated using Dulong and Ruyter models, the woody core and bark were found to have similar energy content. In clones $\mathrm{BH}-4$ and $\mathrm{BH}-8$, the woody core had more energy than bark, but a different trend was observed in clones BH-10 and $\mathrm{BH}-11$, where bark had more energy than the woody core (in Table 4).

\section{DISCUSSION}

\section{OVERALL CHEMICAL COMPOSITION}

Acetone-soluble extractives are relatively hydrophobic, containing terpenes, sterols, and fatty acids. Hot-water soluble extractives are low molecular weight phenolics and carbohydrates. In hardwood, triterpenoids and steroids, which are linked with fatty acids through ester linkages, are parenchyma resins located in parenchyma cells (Sjostrom, 1993). Most phenolic extractives, such as stilbenes, lignans, and tannins, originate from a phenylpropanoid structure.

Bark has more extractives than the woody core, both for acetone-solubles and hot-water solubles (Table 1). Triterpenoids were abundant in the bark; in particular, betulinol was abundant in the outer bark of birch. Most bark has large amount of tannins, compared with woody core biomass (Sjostrom, 1993).
Table 3 | Elementary composition of wood and bark [unit: \% (wt/wt)].

\begin{tabular}{llllll}
\hline & Clones & C & H & N & O \\
\hline Woody core & BH-4 & 46.87 & 6.21 & 1.21 & 45.71 \\
& BH-8 & 46.58 & 6.19 & 1.36 & 45.87 \\
& BH-10 & 46.12 & 6.20 & 1.38 & 46.30 \\
& BH-11 & 45.65 & 6.03 & 1.28 & 47.04 \\
Bark & BH-4 & 45.66 & 6.27 & 0.79 & 47.28 \\
& BH-8 & 45.01 & 6.27 & 1.20 & 47.52 \\
& BH-10 & 45.52 & 6.54 & 2.06 & 45.88 \\
& BH-11 & 44.89 & 6.60 & 2.44 & 46.08
\end{tabular}

Table 4 | Energy content of wood and bark biomass based on model calculation (unit: $\mathrm{MJ} / \mathbf{k g}$ ).

\begin{tabular}{llll}
\hline & Clones & CV1 & CV2 \\
\hline Woody core & BH-4 & 16.54 & 17.32 \\
& BH-8 & 16.39 & 17.16 \\
& BH-10 & 16.17 & 16.95 \\
Bark & BH-11 & 15.63 & 16.44 \\
& BH-4 & 15.94 & 16.74 \\
& BH-8 & 15.68 & 16.48 \\
& BH-10 & 16.53 & 17.29 \\
& BH-11 & 16.37 & 17.13
\end{tabular}

CV1, energy content based on Dulong model; CV2, energy content based on Ruyter model.

Some tannins are not soluble in acetone or hot water, but are rendered soluble using alkaline extraction. Higher lignin content in bark than in woody core may result from tannins that are not soluble in solvent extraction, and which, through Klason lignin determination through acid hydrolysis during, were considered as lignin.

\section{CARBOHYDRATE COMPOSITION}

Willow is hardwood, and hence, it has cellulose and xylan as its main polysaccharides, and small amounts of mannose and galactose as minor hemicelluloses. Cellulose and xylan content in bark was significantly lower than in the woody core but galactan and arabinan were higher in the bark than in the woody core biomass. In chemical compositional analysis of 20-year-old yellow poplar 
biomass, the inner and outer bark were found to have less cellulose $(37.8 \%$ for inner bark, 35.5\% for outer bark) than trunk biomass $(46.2 \%)$. Xylan content in the wood trunk was $17.5 \%$, significantly higher than the values of 9.0 and $8.7 \%$, for outer and inner bark, respectively (Myeong et al., 2010). In chemical compositional comparison of the bark and wood of juniper, the wood was found to have higher glucan, galactan, and xylan content than bark, but bark had more arabinan than wood (Kim et al., 2007). That trend was also observed in case of Douglas-fir carbohydrate compositional analysis (Robinson et al., 2002). In hemicelluloses, hardwoods have different chemical composition compared with softwood. Main hemicelluloses in hardwood is glucuronoxylan compared with (galacto)glucomannan in softwood. Goat willow is hardwood, but juniper and Douglas-fir are softwood.

\section{ELEMENTARY COMPOSITIONAL ANALYSIS}

During fuel burning, regulated gas emissions can be generated. Nitrogen oxides and sulfur oxides cause acid rain. Most wood biomass does not contain sulfur, but small amounts of nitrogen exist in the bark and woody core of willow biomass (Table 3 ). The amounts of nitrogen oxide emissions are proportional to the nitrogen content in the fuel (Johansson et al., 2004). Nitrogen content in the wood core was $1.2-1.4 \%$, but high variation was observed in the bark (ranging from 0.8 to $2.4 \%$ ).

\section{ENERGY CONTENT}

Lignocellulosic biomass can be converted to carbon dioxide and water through oxidation reactions. The energy content calculated using the Ruyter model was higher than that calculated using the Dulong model (Minowa et al., 1998). Except in the case of BH-11 clones, woody core biomass had more energy content than bark biomass, but this difference did not exceed $5 \%$.

Natural gas or liquid fuel generates little or no ash during combustion. However, solid lignocellulosic biomass has ash in its components, leading to the generation of ash after burning. Ash formation during biomass burning is a function of the ash content and ash composition. Different sources of biomass have different ash contents, ranging from $0.3 \%$ (stem wood sawdust) to $10.7 \%$ (reed canary grass) (Gilbe et al., 2008). Ash content in the woody core of different clones of Salix was found to be $0.6-1.1 \%$, compared with $3.8-4.7 \%$ in the bark. Some ash components can lead to slagging by metal oxides, which causes malfunction of the biomass boiler. Quartz $\left(\mathrm{SiO}_{2}\right)$, kermanite $\left(\mathrm{Ca}_{2} \mathrm{Mg}\left(\mathrm{SiO}_{7}\right)\right)$, and merwinite $\left(\mathrm{Ca}_{3} \mathrm{Mg}\left(\mathrm{SiO}_{4}\right)_{2}\right)$ were identified as the main crystalline materials causing slagging in Salix burned ash (Gilbe et al., 2008). Bark biomass not only has more ash content than the woody core, but also includes more harmful components for slagging. Silica, magnesium, and calcium content in bark were two to three times higher than in woody core biomass (Table 5). For purposes of using willow biomass for solid fuel raw material, careful separation of woody core and bark is thus needed.

\section{CONCLUSION}

Differences were observed between the woody core and bark of willow, in terms of chemical composition, carbohydrate composition, ash content, and major inorganics. There are differences among the four clones of goat willow ( $S$. caprea). Woody core biomass of willow had superior solid fuel characteristics compared
Table 5 | Composition of ashes on wood and bark (unit: $\mathbf{m g} / \mathrm{kg}$ of biomass).

\begin{tabular}{rlrrrrrr}
\hline & Clones & Ash & Mg & Ca & Si & P & K \\
\hline Woody core & BH-4 & 11000 & 500 & 2800 & 20 & 800 & 1900 \\
& BH-8 & 11000 & 500 & 2300 & 40 & 600 & 1900 \\
& BH-10 & 8000 & 300 & 1900 & 20 & 400 & 1300 \\
Bark & BH-11 & 6000 & 300 & 1000 & 30 & 400 & 1800 \\
& BH-4 & 38000 & 1800 & 9500 & 120 & 1500 & 6000 \\
& BH-8 & 46000 & 2200 & 13000 & 130 & 1400 & 5300 \\
& BH-10 & 41000 & 1400 & 9700 & 120 & 1400 & 5400 \\
& BH-11 & 47000 & 1800 & 11500 & 130 & 1500 & 6600 \\
\hline
\end{tabular}

to bark biomass, owing to the higher heating values and greater ash content. The inorganic content, which causes slagging during combustion, was higher in bark biomass than in the woody core. Silica content in bark was three to six times more than woody core, which requires careful control of bark-based solid fuels for slagging control.

\section{ACKNOWLEDGMENTS}

This research was supported by Basic Science Research Program through the National Research Foundation of Korea (NRF) funded by the Ministry of Education (2013R1A1A2004658).

\section{REFERENCES}

Cho, D. H., Kim, Y. H., Park, J.-M., Sim, J., Kim, B.-R., and Shin, S.-J. (2012). Characteristics of xylose and glucuronic acid at concentrated sulfuric acid hydrolysis. J. Korea TAPPI. 44, 9-14. doi:10.7584/ktappi.2012.44.3.009

Cochrane, M. A., and Barber, C. P. (2008). Climate change, human land use and future fires in the Amazon. Glob. Chang. Biol. 15, 601-612. doi:10.1111/j.13652486.2008.01786.x

Dušek, J., and Kvet, J. (2006). Seasonal dynamics of dry weight, growth rate and root/shoot ratio in different aged seedlings of Salix caprea. Biologia 61, 441-447. doi:10.2478/s11756-006-0074-0

Filbakk, T., Jirjis, R., Nurmo, J., and Hoibo, O. (2011). The effect of bark content on quality of Scots pine (Pinus sylvestris L.) pellets. Biomass Bioenergy 35, 3342-3349. doi:10.1016/j.biombioe.2010.09.011

Fischer, G., Prieler, S., and van Velthuizen, H. (2005). Biomass potentials of miscanthus, willow and poplar: results and policy implications for Eastern Europe, Northern and Central Asia. Biomass Bioenergy 28, 119-132. doi:10.1016/j. biombioe.2004.08.013

Gilbe, C., Ohman, M., Lindstrom, E., Bostrom, D., Backman, R., Samuelsson, R., et al. (2008). Slagging characteristics during residential combustion of biomass pellets. Energy Fuels 22, 3536-3543. doi:10.1021/ef800087x

Han, S.-H., Cho, D. H., Kim, Y. H., and Shin, S.-J. (2013a). Biobutanol production from 2-year-old willow biomass by acid hydrolysis and acetone-butanol-ethanol fermentation. Energy 61, 13-17. doi:10.1016/j.energy.2013.04.069

Han, S.-H., Shin, S.-J., Kim, B.-R. O., Aggagan, N. S., and Yun, C.-W. (2013b). Growth, chemical composition and energy contents of seven clones of one-yearold Salix caprea L. as short rotation coppice. Asia Life Sci. 22, 413-426.

Host, G. E., Isebrands, J. G., and Perttu, K. L. (1996). Modeling short rotation forestry growth: an international workshop. Biomass Bioenergy 11, 73-74. doi:10.1016/0961-9534(96)00013-X

Johansson, L. S., Leckner, B., Gustavsson, L., Cooper, D., Tullin, C., and Potter, A. (2004). Emission characteristics of modern and old-type residential boilers fired with wood logs and wood pellets. Atmos. Environ. 38, 4183-4195. doi:10.1016/j.atmosenv.2004.04.020

Jug, A., Hofmann-Schielle, C., Makeschin, F., and Rehfuess, K. E. (1999). Shortrotation of balsam poplars, aspen and willow on former arable land in the Federal Republic of Germany, II. Nutritional status and bioelement export by harvested shoot axes. For. Ecol. Mangage. 121, 67-83. doi:10.1016/S0378-1127(98)00557-X 
Kim, E. W., Karthikeyan, K. G., and Tshabalala, M. A. (2007). Adsorption mechanism of cadmium on juniper bark and wood. Bioresour. Technol. 98, 588-594. doi:10.1016/j.biortech.2006.02.024

Klass, D. L. (1995). Biomass energy in North American policies. Energy Policy 23, 1035-1048. doi:10.1016/0301-4215(95)00095-X

Klass, D. L. (1998). Biomass for Renewable Energy, Fuels, and Chemicals. San Diego: Academic Press.

Lewandowski, I. M., Clifton-Brown, J. C., Scurlock, J. M. O., and Huisman, W. (2000). Miscanthus: European experience with a novel energy crop. Biomass Bioenergy 19, 209-227. doi:10.1016/S0961-9534(00)00032-5

Meers, E., Vandecasteele, B., Ruttens, A., Vangronsveld, J., and Tack, F. M. G. (2007). Potential of five willow species (Salix spp.) for phytoextraction of heavy metals. Environ. Exp. Bot. 60, 57-68. doi:10.1016/j.envexpbot.2006.06.008

Meikle, R. D. (1984). Willows and Poplars of Great Britain and Ireland. London: Botanical Society of the British Isles, 4.

Minowa, T., Kondo, T., and Sudirjo, S. T. (1998). Thermochemical liquefaction of Indonesian biomass residue. Biomass Bioenergy 14,517-524. doi:10.1016/S09619534(98)00006-3

Mirck, J., Lsebrands, J. G., Verwijst, T., and Ledin, S. (2005). Development of shortrotation willow coppice systems for environmental purposes in Sweden. Biomass Bioenergy 28, 219-228. doi:10.1016/j.biombioe.2004.08.012

Myeong, S., Han, S.-H., and Shin, S.-J. (2010). Analysis of chemical composition and energy contents of different parts of yellow poplar for development of bioenergy technology. J. Korean For. Sco 99, 706-710.

Ohman, M., Boman, C., Hedman, H., Norin, A., and Bostrom, D. (2004). Slagging tendencies of wood pellet ash during combustion in residential pellet burners. Biomass Bioenergy 27, 585-596. doi:10.1016/j.biombioe.2003.08.016

Olabi, A. G. (2012). Development in sustainable energy and environmental protection. Energy 39, 2-5. doi:10.1016/j.energy.2011.12.037

Robinson, J., Keating, J. D., Boussaid, A., Mansfield, S. D., and Saddler, J. N. (2002). The influence of bark on the fermentation of Douglas-fir whitewood prehydrolysis. Appl. Microbiol. Biotechnol. 59, 443-448. doi:10.1007/s00253-0021055-z

Ruyter, H. P. (1982). Coalification model. Fuel 61, 1182-1187. doi:10.1016/00162361(82)90017-5
Senelwa, K., and Sims, R. E. H. (1999). Fuel characteristics of short rotation forest biomass. Biomass Bioenergy 17, 127-140. doi:10.1016/S0961-9534(99)00035-5

Shin, S.-J., and Cho, N.-S. (2008). Conversion factors for carbohydrate analysis by hydrolysis and 1H-NMR spectroscopy. Cellulose 15, 255-260. doi:10.1007/ s10570-007-9156-6

Sivapalan, K., Yunus, M. N. M., Sopian, K., Samsuddin, A. H., and Rahman, R. A. (2003). Modeling the heating value of municipal solid waste. Fuel 82, 1119-1125. doi:10.1016/j.wasman.2013.09.023

Sjostrom, E. (1993). Wood Chemistry, Fundamental and Application. San Diego: Academic Press.

Vervaeke, P., Tack, F. M. G., Navez, F., Martin, J., Verloo, M. G., and Lust, N. (2006). Fate of heavy metals during fixed bed downdraft gasification of willow wood harvested from contaminated sites. Biomass Bioenergy 30, 58-65. doi:10.1016/j.biombioe.2005.07.001

Zamorano, M., Popov, V., Rodriguez, M. L., and Garcia-Maraver, A. (2011). A comparative study of quality properties of palletized agricultural and forestry lopping residue. Renew. Energy 36, 3133-3140. doi:10.1016/j.renene.2011.03.020

Conflict of Interest Statement: The authors declare that the research was conducted in the absence of any commercial or financial relationships that could be construed as a potential conflict of interest.

Received: 03 October 2013; accepted: 17 January 2014; published online: 31 January 2014.

Citation: Han S-H and Shin S-J (2014) Investigation of solid energy potential of wood and bark obtained from four clones of a 2-year old goat willow. Front. Energy Res. 2:5. doi: 10.3389/fenrg.2014.00005

This article was submitted to Bioenergy and Biofuel, a section of the journal Frontiers in Energy Research.

Copyright (c) 2014 Han and Shin. This is an open-access article distributed under the terms of the Creative Commons Attribution License (CC BY). The use, distribution or reproduction in other forums is permitted, provided the original author(s) or licensor are credited and that the original publication in this journal is cited, in accordance with accepted academic practice. No use, distribution or reproduction is permitted which does not comply with these terms. 